\title{
Freeze desalination as point-of-use water defluoridation technique
}

\author{
Fekadu Melak $^{1,4} \cdot$ Argaw Ambelu$^{1} \cdot$ Higemengist Astatkie $^{1} \cdot$ Gijs Du Laing $^{2} \cdot$ Esayas Alemayehu $^{3}$
}

Received: 29 March 2017 / Accepted: 18 February 2019 / Published online: 4 March 2019

(c) The Author(s) 2019

\begin{abstract}
Freeze desalination, i.e., desalination of water by freezing it, may be an option to treat polluted water at individual household level. Taking into account the widespread fluoride contamination of Ethiopian water resources and with the reason that most households in semi-urban and urban areas do have easier accessibility of refrigerators, this study aimed to investigate the defluoridation capacity of freeze desalination and its energy consumption for different water sources. For this purpose, synthetic solutions that emulate the major ion compositions of natural waters (hereafter called simulated water), tap water, and double-distilled water to which variable concentrations of fluoride ions were added were evaluated using home-use insulated refrigerator (BEKO, RRN 2650). The effects of conditions such as initial fluoride concentration, multi-ion existence, fraction of ice frozen, volume of the container, and freezing duration were evaluated in relation to the produced ice quality. It was found that nearly $48 \%$ and $62 \%$ removal of fluoride were achieved from tap water spiked with $10 \mathrm{mg} / \mathrm{L} \mathrm{F}^{-}$and $10 \mathrm{mg} / \mathrm{L} \mathrm{F}^{-}$aqueous solutions, respectively, with a total water recovery of 85 to $90 \%$. The energy consumption predicted to produce the ice from tap water spiked with $10 \mathrm{mg} / \mathrm{L} \mathrm{F}^{-}$and double-distilled water alone was found to be 93.9 and $91.8 \mathrm{~kJ} / \mathrm{L}$, respectively. The results showed that freeze desalination can be a potential technique for fluoride removal from water to be used as drinking water at household level in semi-urban and urban areas as well as in colder regions.
\end{abstract}

Keywords Defluoridation $\cdot$ Energy consumption $\cdot$ Freeze desalination $\cdot$ Freezing point depression

\section{Introduction}

Fluorine is the most electronegative and highly reactive element, which cannot be found in its elemental form in nature. It exists as inorganic (including $\mathrm{F}^{-}$anion) and organic fluoride forms in water. The occurrence of fluoride in groundwater is derived mainly from dissolution of fluoride-containing minerals, rocks, and soils. Most important fluoride-containing minerals are fluorspar $\left(\mathrm{CaF}_{2}\right)$ from sedimentary rocks,

Fekadu Melak

fekadumelak95@gmail.com

1 Jimma Institute of Health, Department of Environmental Health Sciences and Technology, Jimma University, P.O. Box 378, Jimma, Ethiopia

2 Faculty of Bioscience Engineering, Department of Applied Analytical and Physical Chemistry, Ghent University, Ghent, Belgium

3 School of Civil \& Environmental Engineering, Institute of Technology, Jimma University, Jimma, Ethiopia

4 College of Natural Sciences, Department of Chemistry, Jimma University, Jimma, Ethiopia cryolite $\left(\mathrm{Na}_{3} \mathrm{AlFPO}_{6}\right)$ from igneous and granite, sellaite $\left(\mathrm{MgF}_{2}\right)$, villianmite $(\mathrm{NaF})$, and fluoroapatite $\left(\mathrm{Ca}_{5}\left(\mathrm{PO}_{4}\right)_{3} \mathrm{~F}\right)$ (Jagtap et al. 2012; Thole 2013). These minerals are slightly soluble in water. Basically, elevated concentrations of fluoride are common when conditions favor the dissolution or partial dissolution of fluoride-containing minerals mainly in calcium-poor aquifers. Thus, availability of fluoride in groundwater is highly influenced by rock chemistry, hydrologic conditions, residence time, well depth, volcanic activities, fumarolic gases, and presence of thermal waters. Natural phenomena like weathering in association with rifting and rising of geochemical deposits are also among the main causes of fluoride leakage into water bodies (Ayoob and Gupta 2006; Fawell et al. 2006; Tahir and Rasheed 2013). Besides natural sources, the discharges of fluoride-containing effluents into groundwater as well as surface water from increased industrial activities like semiconductors, metal processing, fertilizers, and ceramic-manufacturing industries are other contamination sources of fluoride in water bodies.

Groundwater is the main source of water supply in most rural communities in Africa, particularly in world regions dealing with water scarcity. It is usually free from microbial 
contamination and suspended particles. However, contamination of groundwater by naturally occurring contaminants like fluoride is a common phenomenon. Globally, millions of people are exposed to high concentrations of fluoride (with $>1.5 \mathrm{mg} / \mathrm{L}$ ) through drinking water (Amini et al. 2008). Problems associated with intake of excess fluoride are prevalent in a number of developed and developing countries such as in China, India, Sri Lanka, USA, Asia, and Rift Valley countries in Africa, including Ethiopia (Amini et al. 2008; Jagtap et al. 2012). Particularly, in the main Ethiopian Rift Valley (MER) area, it was estimated that about 8 million inhabitants depend primarily on fluoride-contaminated groundwater for drinking and domestic applications (Reimann et al. 2003; Mohapatra et al. 2009; Tewodros et al. 2010). In a study by Rango et al. (2012), from a total of 148 water samples collected from MER, 48 of 50 well-waters were shown to exceed the WHO drinking water guideline (Rango et al. 2012).

Fluoride consumption brings about either a healthier or detrimental effect in humans. When fluoride level is small $(1-1.5 \mathrm{mg} / \mathrm{L})$ in drinking water, formation of fluoroapatite $\left(\mathrm{Ca}_{5}\left(\mathrm{PO}_{4}\right)_{3} \mathrm{~F}\right)$ which is resistant to acid attack leads to prevention of dental caries. In case of prolonged exposure and high concentration of fluoride, many people suffer from conditions of mild dental fluorosis to crippling skeletal fluorosis (Mohapatra et al. 2009). Accordingly, different countries set maximum contaminated limit (MCL) for fluoride in drinking waters. A guideline value of $1.5 \mathrm{mg} / \mathrm{L}$ was therefore set by $\mathrm{WHO}$ as a level at which dental fluorosis being minimal from drinking water sources.

Various methods have been employed to treat fluoridecontaining water. However, most are facing challenges, especially when they should be used in developing countries. The conventional water treatments like biological processes are often ineffective to treat chemical substances. Adsorption processes are effective mainly for low concentrations, and chemical treatments like precipitation and coagulation are expensive and produce high amounts of sludge or secondary pollutants which need additional treatments. Membrane processes are limited by fouling problems, and thermal processes are costly (Lorain et al. 2001; Durmaz et al. 2005; Mohapatra et al. 2009). Freeze desalination is an alternative method, based on salt rejection from water during freezing. Salt rejection in freeze desalination is due to the small dimensions of the ice crystal lattice that excludes the salt ions during partial freezing instead of being incorporated in the crystal lattice of the ice. The rejection of salt ions out of the solid phase (ice) is highly related to the hydration free energy and hydrated or ionic radius of the salt ions. Hydration free energy is the energy which indicates the stability of the hydrated ions compared to their unhydrated counterparts. Ions with smaller energy of hydration have less association with water, and hence, it is more likely to be rejected from ice phase. According to Born model, hydration free energy is approximately related to the ionic charge of ions in a quadratic fashion. The ionic/hydrated radius of ions is dependent on many factors such as charge of ions whether cationic or anionic, size of ions, ion-water interaction potential, and coordination of ions with water (Hummer et al. 1996; Lu and Xu 2010; Mahdavi et al. 2011). Ionic/hydrated radius of salt ions in turn affects the ion rejection from ice crystals either by affecting the size of ions in water or by changing the affinity, i.e., ion-water interactions. Essentially, Pauling radius of ions influences the strength of hydration. Thus, the lower the hydration strength of ions, the higher the percentage removal of ions through freeze desalination (Hummer et al. 1996; Kang et al. 2014; Melak et al. 2016; Tansel 2012). Additionally, the mechanism of salt rejection from ice phase by freezing could be because solubility of salt ions is negligible in the ice phase as compared to solubility in water (Vrbka and Jungwirth 2005). Freeze desalination is a natural phenomenon based on the fact that ice crystals are essentially made up of pure water, and it is the properties of pure water. Salt ions possess anti-freeze effect (e.g., freezing point depression) which has been shown by molecular simulations; it happens that when the surface of ice reduced in the salt ion density, the progression of freezing and ice crystal growth from pure water occurred. In general, the crystal ice formation is more likely to form in the surfaces than in the bulk phase of the solution (Zhou et al. 2002).

The use of cost effective energy sources can make freeze desalination technology a promising tool in the production of potable water. Improvements of freeze desalination over other methods (e.g., thermal processes) have been reported by Melak et al. (2016) and references therein. The advantages including immunity to fouling and corrosion problems, possibility of working in relatively wide salinity ranges and compositions of the feed water, avoidance of scaling as well as avoidance of the need for pre-treatment are well known (Fletcher 1966; Shone 1987; Wang and Chung 2012; Chang et al. 2016; Melak et al. 2016). Freeze desalination processes possess advantages of low operating temperatures, which minimize scaling and corrosion problems (Rahman et al. 2006). It is highly energy efficient than thermal processes. The latent heat of freezing is low compared to the latent heat of evaporation, leading to save about $70 \%$ of the energy required by the conventional thermal process. The cost effectiveness of freeze desalination could also be explained due to the use of renewable energy resources, for instance, the use of LNG cold energy, waste energy (Cao et al. 2015). By the use of hybrid methods, combining freezing and membrane desalination processes, approximately $25 \%$ of energy consumed could be saved when compared to conventional RO desalination (Baayyad et al. 2014). Although with such several advantages of freezing, the applicability of freeze desalination for defluoridation and energy consumption 
during the process has hardly been studied. Only a general remark by a conference presentation was indicated to reduce fluoride concentration down to the desired drinking water standards using partial freezing of water samples (Hosseini et al. 2012). There is no well-designed study so far considering freeze defluoridation efficiencies and energy consumption evaluation during the process. Moreover, it is important to develop easily applicable methods, which do not require high-tech solutions and highly skilled man power, for use at individual household levels in rural, semi-urban as well as urban areas of developing nations.

Accordingly, the main aim of this work was to evaluate the defluoridation efficiency of freeze desalination as point-of-use fluoride removal technique, and elucidate the freezing point depression and energy consumption during the process.

\section{Materials and methods}

\section{Reagents}

Chemicals used were of analytical grade. A stock solution of $1000 \mathrm{mg} / \mathrm{L} \mathrm{F}^{-}$was prepared by dissolving $2.21 \mathrm{~g}$ of $\mathrm{NaF}$ (Finkem, Italy) in double-distilled water. Calibration standards of $0.01,0.1,1,10$, and $100 \mathrm{mg} / \mathrm{L}$ were prepared from the $1000 \mathrm{mg} / \mathrm{L} \mathrm{F}^{-}$stock solution. Total ion strength adjustment buffer (TISAB) was prepared from disodium EDTA salt (ALPHA Chemika, Mumbai), $\mathrm{NaCl}$, and glacial acetic acid. The $\mathrm{pH}$ of the buffer was adjusted using $6 \mathrm{M} \mathrm{NaOH}$. Working solutions of $2,5,10,15$, and $20 \mathrm{mg} / \mathrm{L} \mathrm{F}^{-}$were prepared by diluting the stock solution prior to each experiment. Synthetic solutions that include major ion compositions of natural waters (referred to as simulated water) were prepared from salts of $\mathrm{NaCl}, \mathrm{K}_{2} \mathrm{SO}_{4}, \mathrm{KNO}_{3}, \mathrm{Na}_{2} \mathrm{CO}_{3}, \mathrm{NaHCO}_{3}$, and $\mathrm{MgCl}_{2}$. Erichrome black T (EBT) indicator was used in total hardness determination. For iron determination in tap water, concentrated $\mathrm{HCl}$, hydroxylamine, acetate buffer, and 1-10-phenanthroline were utilized. Moreover, $\mathrm{H}_{2} \mathrm{SO}_{4}$ (titrant), phenolphthalein, bromo-cresol green indicator, $\mathrm{NaOH}$, Na-EDTA, and Calcon indicator were used to determine both calcium hardness and alkalinity.

\section{Analytical methods}

The amount of fluoride in the melted ice and standards was determined using fluoride ion selective electrode (Combination Fluoride Electrode, Mettler-Toledo AG) based on the standard procedure of perfectION ${ }^{\mathrm{TM}}$ guide book (MettlerToledo 2011). For this, TISAB was prepared by mixing $4 \mathrm{~g}$ disodium EDTA salt, $58 \mathrm{~g} \mathrm{NaCl}$, and $57 \mathrm{~mL}$ of glacial acetic acid in a $1 \mathrm{~L}$ volumetric flask and stirring to dissolve the compounds. Then, $125 \mathrm{~mL}$ of $6 \mathrm{M} \mathrm{NaOH}$ was added to adjust the $\mathrm{pH}$ to a value between 5 and 5.5, and the flask was filled to the mark with double-distilled water. The amount of fluoride in the calibration standards as well as in the melted ice was determined using the fluoride ion selective electrode in a 1:1 mixture of sample/standard and buffer (TISAB). Therefore, $25 \mathrm{~mL}$ of the sample and $25 \mathrm{~mL}$ of TISAB solution were mixed and then stirred for 3 min with a magnetic stirrer. Then, the electrode potentials of sample solutions were compared with those of fluoride standards and the amount of fluoride in sample was determined.

The amount of chloride and nitrate in the sampled tap water was analyzed using argentometric titration (Mohr method) and the phenol disulphonic acid (PDA) method, respectively (Eaton et al. 1995). In the PDA method of nitrate determination, nitrate reacts with phenol disulphonic acid producing nitro-derivatives in a basic medium, developing a yellow color. The colored complex produced an intensity of absorption which is proportional to the concentration of $\mathrm{NO}_{3}{ }^{-}$present in the sample and determined using (DR 5000, Hach, Germany) UV-Vis spectrophotometer.

Iron $\left(\mathrm{Fe}^{2+}\right)$ was determined with UV-Vis spectroscopy using phenantroline method. Ferric iron is brought into solution, reduced to the ferrous state by boiling with acid and hydroxylamine, and treated with 1, 10-phenanthroline at $\mathrm{pH} 3.2$ to 3.3. Total iron amount was analyzed from iron-phenanthroline complex with a spectrophotometer at a fixed wavelength of $508 \mathrm{~nm}$ according to the literature (Eaton et al. 1995). Total dissolved solid (TDS) of the water sample was determined according to Laporte-Saumure et al. (2010). The sample was filtered with a glass fiber filter, and then, the water was evaporated at $180{ }^{\circ} \mathrm{C}$ in a porcelain cup of known weight. The sample was weighed after the solvent was evaporated. Parameters such as total hardness and calcium hardness were determined using titrimetric methods. Conductivity and $\mathrm{pH}$ were measured using a multi-parameter probe of Hach (HQ40d). Turbidity of the water sources was examined using a portable turbidity meter (Wagtech International, Wag-WT3020).

\section{Experimental setup}

A batch of capped plastic beakers ( $4 \mathrm{~cm}$ height by $2.5 \mathrm{~cm}$ radius) with a $3.1-\mathrm{cm}$ rod fixed from the cap and inserted down to the solution was employed as in Fig. 1. Samples containing $50 \mathrm{~mL}$ of different concentrations of fluoride aqueous solutions, and simulated water containing ions of $\left(\mathrm{Mg}^{2+} 50 \mathrm{mg} / \mathrm{L}, \mathrm{Na}^{+} 446 \mathrm{mg} / \mathrm{L}, \mathrm{K}^{+} 185 \mathrm{mg} / \mathrm{L}\right.$, $\mathrm{HCO}_{3}{ }^{-} 470 \mathrm{mg} / \mathrm{L}, \mathrm{CO}_{3}{ }^{2-} 130 \mathrm{mg} / \mathrm{L}, \mathrm{SO}_{4}{ }^{2-} 150 \mathrm{mg} / \mathrm{L}$, $\mathrm{NO}_{3}{ }^{-} 100 \mathrm{mg} / \mathrm{L}$, and $\left.\mathrm{Cl}^{-} 250 \mathrm{mg} / \mathrm{L}\right)$ spiked with $10 \mathrm{mg} / \mathrm{L}$ $\mathrm{F}^{-}$, were prepared and tested for freeze defluoridation capacity. Each solution was placed into the refrigerator for a predetermined time to undergo partial freezing, producing ice. This experiment was conducted in triplicate. Similarly, after 
Fig. 1 Scheme of experimental setup used to study freeze separation of fluoride

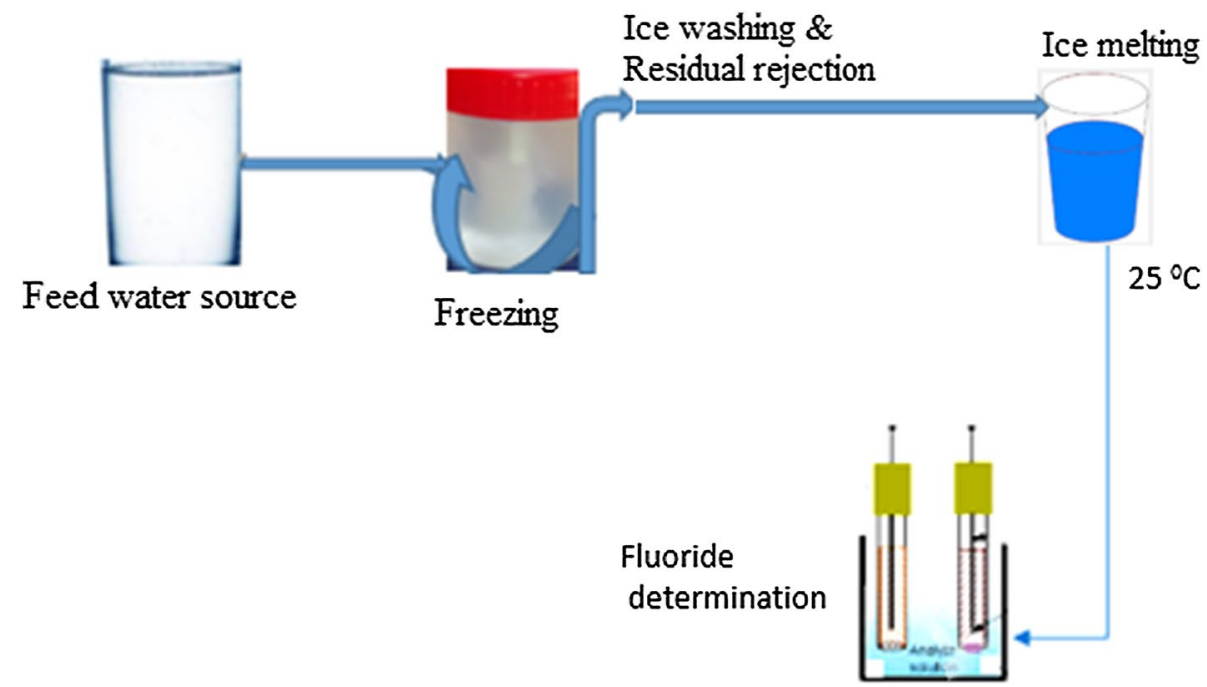

parameter optimization, tap water spiked with $10 \mathrm{mg} / \mathrm{L}$ $\mathrm{F}^{-}$was tested for freeze separation. To cast off the solution that remained unfrozen, a 3.1-cm rod, attached with the cap, was inserted into each of the solutions. Double-distilled water was pre-cooled in a freezer to $5{ }^{\circ} \mathrm{C}$ being used for washing of produced ice. The ice crystals were separated and rinsed once with 15-20 mL cold doubled-distilled water to separate the weakly adsorbed fluoride ions from the surface of the ice. Subsequently, the ice crystals produced were melted by letting samples at room temperature and the mass of melted ice was recorded. Finally, melted ice was analyzed for fluoride concentration using a fluoride Ion Selective Electrode, Mettler-Toledo. The schematic presentation of the experimental process is shown in Fig. 1.

\section{Evaluation of freeze desalination}

The efficiency of freeze separation $(E)$ and freezing ratio $\left(R_{\mathrm{F}}\right)$ were evaluated through Eqs. (1) and (2).

$E=\left(1-C_{\mathrm{s}} * V_{\mathrm{s}} / C_{o} * V_{o}\right) * 100$

$R_{\mathrm{F}}=\frac{\mathrm{V}_{\mathrm{s}}}{\mathrm{V}_{o}}$

where $E$ is the efficiency of freeze separation and $R_{\mathrm{F}}$ is freezing ratio, $V_{O}$ initial volume of fluoride-containing solution/ simulated water, $V_{\mathrm{S}}$ volume of the solid phase (Ice) after melting $(\mathrm{mL})$, Co initial concentration of fluoride in solution/simulated water $(\mathrm{mg} / \mathrm{L})$, and $C_{\mathrm{S}}$ concentration of fluoride in ice phase $(\mathrm{mg} / \mathrm{L})$.

To describe the capacity of freeze defluoridation, the effective partition constant $(K)$ was calculated using Eq. (3).

$K=C_{\mathrm{S}} / C_{\mathrm{L}}$ where $C_{\mathrm{S}}(\mathrm{wt} \%)$ and $C_{\mathrm{L}}(\mathrm{wt} \%)$ are fluoride concentrations in the ice phase and solution phase, respectively. The value of the partition constant $(\mathrm{K})$ varies between 0 and 1 , where 0 indicates the absence of fluoride ions in the ice (solid phase) and 1 indicates the presence of equal amounts of fluoride in the concentrated residue (unfrozen phase) and in the ice phase. A small increase in volume of the ice phase results in a small decrease in the volume of the solution phase $\left(-\mathrm{d} V_{\mathrm{L}}\right)$, whereby the concentration of the solutes increase in the solution phase by $\mathrm{d} C_{\mathrm{L}}$. The mass balance equation of the solute is given by Eq. (4).

$C_{\mathrm{L}} V_{\mathrm{L}}=-C_{\mathrm{s}} \mathrm{d} V_{\mathrm{L}}+\left(C_{\mathrm{L}}+\mathrm{d} C_{\mathrm{L}}\right)\left(V_{\mathrm{L}}+\mathrm{d} V_{\mathrm{L}}\right)$

Substituting Eq. (3) in (4) and rearranging provides:

$\left(\mathrm{d} C_{\mathrm{L}}+C_{\mathrm{L}} / C_{\mathrm{L}}\right) /\left(\mathrm{d} V_{\mathrm{L}} / V_{\mathrm{L}}\right)=K-1$

Integrating Eq. (5) yields:

$(1-K) \log \left(V_{\mathrm{L}} / V_{o}\right)=\log \left(C_{o} / C_{\mathrm{L}}\right)$

where $C_{\mathrm{o}}$ is the initial fluoride concentration, $V_{\mathrm{L}}$ is volume of unfrozen liquid phase $(\mathrm{mL})$, and $V_{\mathrm{o}}$ is the initial volume of solution/simulated water. The equations assume complete mixing in the solution phase but no mixing in the ice phase (Liu et al. 1997).

\section{Energy estimation and freezing point depression}

Freezing point depression is a colligative property which describes the process in which adding solute to solvent lowers the freezing point of a pure solvent. Freezing point depression is a colligative property, and hence, it is dependent on the amount of solutes added not on their identity. It is directly related to the molality of solutes (Halde 1980). Freezing point depression can be expressed as:

$\Delta T_{\mathrm{f}}=i K_{\mathrm{f}} m$ 
where $\Delta T_{\mathrm{f}}$ is the change in freezing temperature of a solution relative to the pure substance (the freezing point depression), $K_{\mathrm{f}}$ is the cryoscopic constant related to the identity of the solvent (for water $K_{\mathrm{f}}$ is $1.86{ }^{\circ} \mathrm{C} / m$ or $1.86 \mathrm{~K} \mathrm{~kg} / \mathrm{mol}$ ), and $m$ molality in moles per $\mathrm{kg}$ of solvent. The van't Hoff factor $(i)$ is a factor reflecting the effect of a solute upon the colligative properties of substances. The van't Hoff factor $(i)$ is equal to 1 for most non-dissociated ions in water and equal to the number of dissociated species for dissolved solutes in water.

Energy released upon freezing of water includes activation energy for ice nucleation, latent heat or enthalpy of fusion, and the energy to stabilize structure of the ice during freezing to attain freezer's temperature. The proposed energy estimation equation for a given mass of a substance can be given as:

$E=m L(Q)+C_{\mathrm{w}} m_{\mathrm{w}} \Delta T\left(293.55-T_{\mathrm{fs}}\right)+C_{i} m_{i} \Delta T\left(T_{\mathrm{fs}}-(249.15 \mathrm{~K})\right)$

where,

$Q$ is the amount of energy released or absorbed during the change of phase of the substance (in kJ),

$C_{\mathrm{w}}$ is specific heat capacity of water $(4.186 \mathrm{~kJ} / \mathrm{kg} \mathrm{K})$,

$C_{\mathrm{i}}$ is specific heat capacity of ice (at $253.15 \mathrm{~K}=1.943 \mathrm{~kJ} /$

$\mathrm{kg} \mathrm{K}$ and at $273.15=2.050 \mathrm{~kJ} / \mathrm{kg} \mathrm{K}$ ),

$m$ is the mass of the substance (in $\mathrm{kg}$ ), and

$L$ is the specific latent heat for a particular substance $(\mathrm{KJ} /$ $\mathrm{kg}$ ) (latent heat fusion for water is $334 \mathrm{~kJ} / \mathrm{kg}$ ).

Refrigerator's inside temperature $(249.15 \mathrm{~K})$ and refrigeration cycle efficiency $\approx 4$.

$\Delta T$ is the change in temperature in degree Kelvin.

$T_{\mathrm{fs}}$ is the freezing point of simulated water and fluoridecontaining solution, where freezing point of pure water is assumed $273.15 \mathrm{~K}$.

The following assumptions were considered while estimating the energy consumed during freeze desalination: (a) Since the surface of the container is smooth, the ice nucleation process was assumed to be homogeneous.

(b) Pressure being 1 atm for the condition of specific latent heat and specific heat capacity.

(c) The solution is assumed to be ideal, which implies that ion pairing in all electrolytes within the solution is absent.

(d) No supercooling has occurred.

\section{Results and discussion}

Physicochemical parameters of initial fluoride-containing solutions/simulated water and melted ice are presented in Table 1. It was found that the conductivity of the ice produced from tap water spiked with $10 \mathrm{mg} / \mathrm{L} \mathrm{F}^{-}(53.4 \mu \mathrm{S} /$ $\mathrm{cm})$ was nearly half of the conductivity of tap water spiked with $10 \mathrm{mg} / \mathrm{L} \mathrm{F}^{-}$before partial freeing $(97.2 \mu \mathrm{S} / \mathrm{cm})$. Previous studies (Mahdavi et al. 2011; Badawy 2015; Chang et al. 2016; Melak et al. 2016) showed that total dissolved salts (TDS) of the treated water via freezing decreased about two-fourfold from initial concentrations, and desalting was highly influenced by the properties of the initial employed water. It was observed that the salt concentration in the water generated by melted ice decreased with increasing freeze duration until the volume of unfrozen water became very small (up to $15 \%$ of initial volume used). Surprisingly, the experimental data have shown that the mass of ice produced from simulated water spiked with $10 \mathrm{mg} / \mathrm{L} \mathrm{F}^{-}$is higher than that produced from double-distilled water ('pure water') under the same experimental conditions. One of the reasons may be once the ice nucleation started, the ice crystal formation in the simulated water spiked with $10 \mathrm{mg} / \mathrm{L} \mathrm{F}^{-}$might be faster compared to pure water under the given experimental conditions (small volume, $50 \mathrm{~mL}$ of initial solution/simulated water and relatively high concentration of salt ions). Another reason could be the change of processes occurring in the interface between the ice and solution phase when the solute particles' concentration increased in the bulk solution.

Table 1 The physicochemical characteristics of sample water/solution

\begin{tabular}{|c|c|c|c|c|c|c|}
\hline Item & $\begin{array}{l}\text { Conductiv- } \\
\text { ity }(\mu \mathrm{S} / \mathrm{cm})\end{array}$ & $\mathrm{pH}$ & $\begin{array}{l}\text { Turbidity } \\
\text { (NTU) }\end{array}$ & $\mathrm{DO}(\mathrm{mg} / \mathrm{L})$ & $\begin{array}{l}\text { Mass of sampled } \\
\text { ice }(g) \text {, after melt- } \\
\text { ing }\end{array}$ & $\begin{array}{l}\text { Mass of unfro- } \\
\text { zen residue }(g)\end{array}$ \\
\hline Simulated water spiked with $10 \mathrm{mg} / \mathrm{L} \mathrm{F}^{-}$ & 2630 & 9.22 & & 7.00 & & \\
\hline Ice obtained from simulated water spiked with $10 \mathrm{mg} / \mathrm{L} \mathrm{F}^{-}$ & 2250 & 9.12 & & 6.97 & 39.67 & 8.05 \\
\hline Double-distilled water & 2.72 & 6.64 & 0.78 & 6.36 & & \\
\hline Ice from double-distilled water & 1.41 & 6.79 & 0.43 & 6.23 & 37.50 & 10.43 \\
\hline Tap water spiked with $10 \mathrm{mg} / \mathrm{L} \mathrm{F}^{-}$ & 97.2 & 6.69 & 6.17 & 7.64 & & \\
\hline Ice obtained from tap water spiked with $10 \mathrm{mg} / \mathrm{L} \mathrm{F}^{-}$ & 53.4 & 7.27 & 2.42 & 7.43 & 38.05 & 9.42 \\
\hline
\end{tabular}

Initial volume of solution/simulated water $=50 \mathrm{~mL}$, freezer temperature $249.15 \mathrm{~K}$, freeze duration $2 \mathrm{~h}$. Temperature $297.35 \mathrm{~K}$ during measurement of $\mathrm{pH}$ and conductivity 
The change in the interface processes could be due to the hydration behavior of ions (for instance, $\mathrm{Mg}^{2+}, \mathrm{Na}^{+}, \mathrm{F}^{-}$, and $\mathrm{SO}_{4}{ }^{2-}$ ) in water, which contribute stability and structure of water-water interactions (Dos Santos et al. 2010; Kang et al. 2014). This also could be seen in connection with particles that can catalyze the rate of ice formation through heterogeneous nucleation at temperatures warmer than the homogenous nucleation. Ice nucleation barrier is highly reduced by the existence of impurities leading to heterogeneous nucleation. On top of that, solution-water activity indicating vapor pressure of the solution and the saturation water vapor pressure under the same conditions might play a crucial role (Knopf and Alpert 2013; Wright and Petters 2013). Similar phenomenon that the presence of salt ions enhances ice formation has been expressed by Adeniyi et al. (2016). It is also explained that heterogeneous ice nucleation is stochastic in contrast to homogeneous ice nucleation, being the presence of ionic salts, from simulated water in our case, and impurities leads the produced ice to undergo heterogeneous nucleation (Niedermeier et al. 2011).

\section{Effect of freezing time}

Freeze duration is an important parameter to produce ice. The process of freeze separation for fluoride in aqueous solution and mass fraction of melted ice as a function of freeze duration is given in Fig. 2. When the freeze duration increased, the amount of ice produced increased. It was shown that nearly 55-62\% defluoridation efficiency within $2 \mathrm{~h}$ of freezing was achieved. A longer freeze duration of $2 \mathrm{~h}$ afterward revealed the inclusion of high fluoride contents in the produced ice for the specified conditions. Long

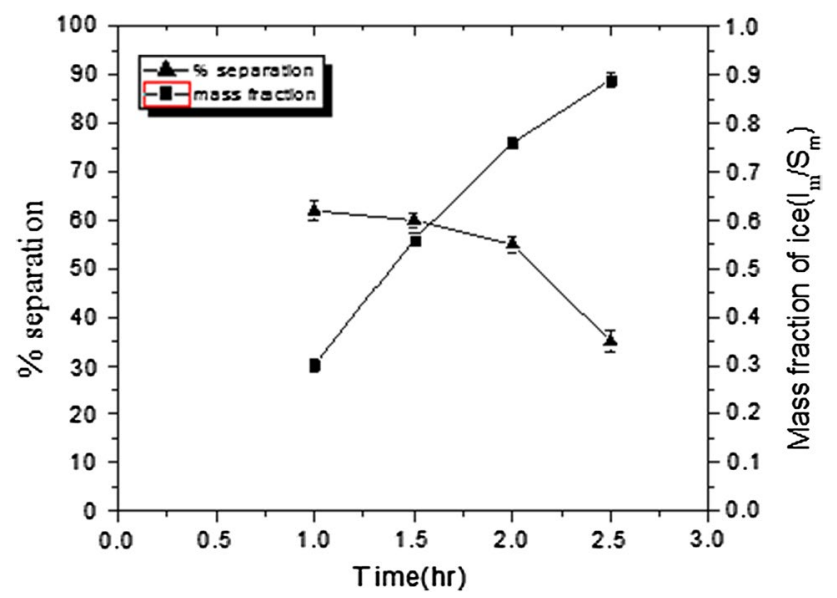

Fig. 2 Effect of freeze duration upon fluoride separation efficiency and fraction of ice produced evaluated as mass of melted ice $\left(I_{\mathrm{m}}\right)$ to mass of total solution $\left(S_{\mathrm{m}}\right)$ from aqueous solution (mean \pm standard deviation, $n=3$; conditions: freezing temperature $249.15 \mathrm{~K}$, initial sample volume $50 \mathrm{~mL}$, initial concentration $10 \mathrm{mg} / \mathrm{L}$ ) freeze duration results in the ice with high salinity because the salinity builds up an interface and tends to inclusions afterward (Chang et al. 2016; Melak et al. 2016). Thus, the optimal duration that leads to small volume of residual water rejection and good quality of ice water production from melted ice was assessed. In this experiment, a longer freeze duration showed a change in the appearance of the ice produced. The inner section of the ice being produced revealed a 'whitish-' colored ice with regular structure, leaving the outer section nearly colorless. Such structure of the ice crystal has been taken as advantage to improve the quality of water produced by thaw off the ice, creating favorable conditions for washing (ESA 2013; Chang et al. 2016). In the experiment, about $10-15 \%$ volume of liquid residue rejection was observed regardless of the initial volume of the sample, acquiring nearly $85 \%$ of water recovery from the melted ice (Fig. 2). Similar high total water recovery in achieving water quality which met the standard for drinkable water from a $144 \mathrm{mg} / \mathrm{L}$ saline water was observed by hybrid desalination process comprising freeze desalination and membrane distillation (Wang and Chung 2012). It is known that when soluble solutes freeze partially, a high extent of salt rejection occurs (Baker 1967; Melak et al. 2016). However, the angle of the container used for freezing and surface roughness highly influence the inclusion of salt ions into the ice (Mtombeni et al. 2013; Hao et al. 2014).

\section{Effect of fluoride concentration and multi-ion occurrence}

The influence of fluoride concentration and multi-ion occurrence (simulated water) upon freeze defluoridation was investigated and is presented in Figs. 3 and 4. In the studied concentration range $(2-20 \mathrm{mg} / \mathrm{L})$, fluoride percent removal reached about $62 \%$ for aqueous solutions and went down to $40 \%$ in the case of simulated water spiked with $10 \mathrm{mg} / \mathrm{L} \mathrm{F}^{-}$. At a fixed duration $(2 \mathrm{~h})$, the percent removal of fluoride gradually decreased as the concentration of fluoride increased. For initial concentrations of fluoride (nearly $\leq 3 \mathrm{mg} / \mathrm{L}$ ) in aqueous solutions, partial freezing reduced to below $1.5 \mathrm{mg} / \mathrm{L}$, which is the drinking water limit set by WHO. For higher fluoride concentrations, several freezing-melting cycles may be advised to make fluoride level to drinkable range. Previous studies have also indicated several freezing-melting cycles are advisable to bring the concentrations below drinking water limits when the salt ions are high in concentration (Badawy 2015). The smaller percent removal of fluoride (40\%) in the case of simulated water spiked with $10 \mathrm{mg} / \mathrm{L} \mathrm{F}^{-}$could be due to an increase in freezing rates once ice nucleation started and the changes of interface phenomenon as described in "Results and discussion" section (explanation of Table 1). This result is well illustrated in Fig. 4. The impacts of freezing rate and added 


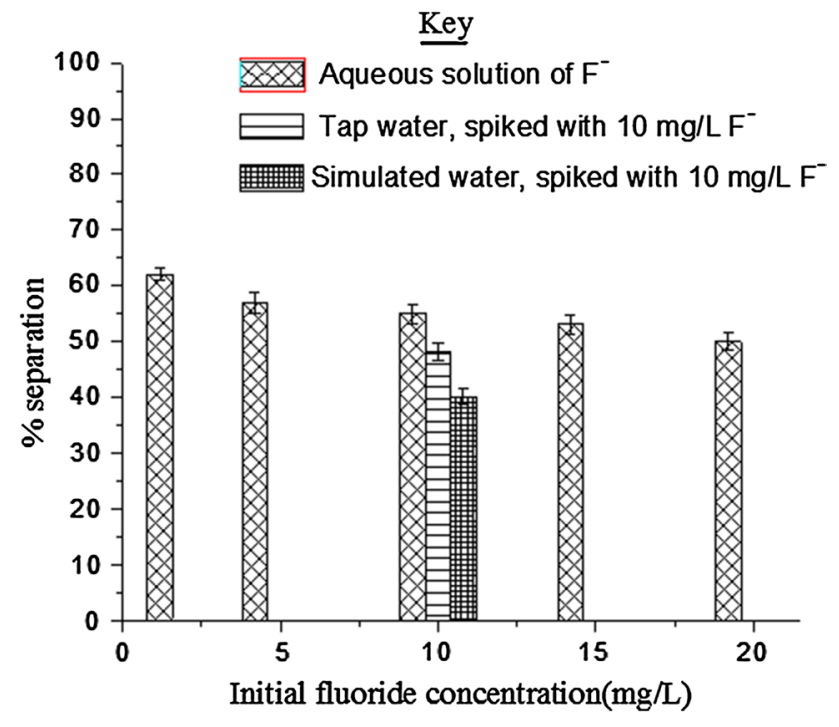

Fig. 3 Effect of initial fluoride concentration on fluoride removal efficiency in tap water, simulated water, and aqueous solutions with a fluoride concentration ranging up to $20 \mathrm{mg} / \mathrm{L}$ (mean \pm standard deviation, $n=3$; conditions: freezing temperature $249.15 \mathrm{~K}$, initial sample volume $50 \mathrm{~mL}$, freeze duration $2 \mathrm{~h}$ )

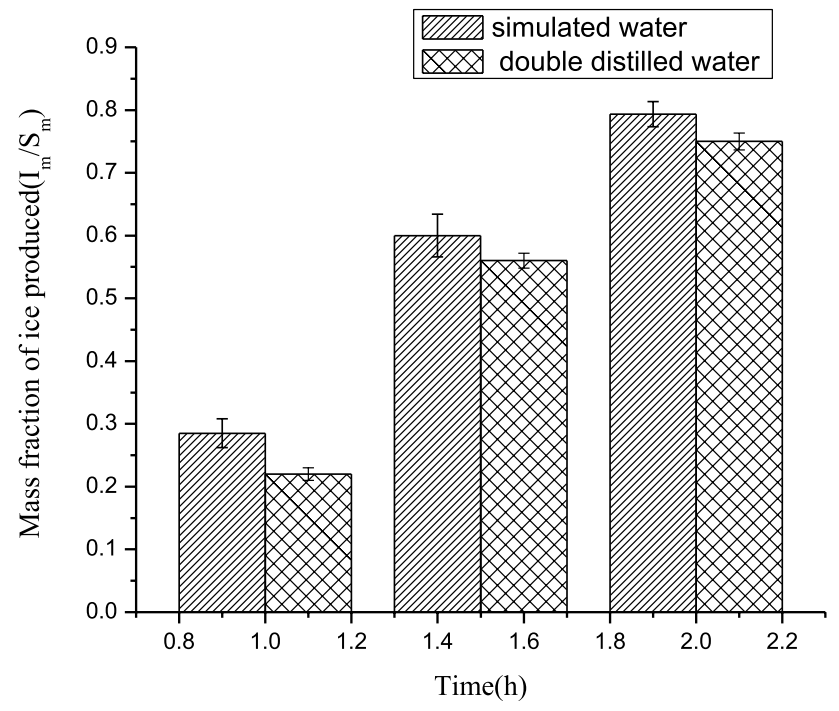

Fig. 4 Mass fraction of ice evaluated as mass of melted ice $\left(I_{\mathrm{m}}\right)$ to mass of total solution $\left(S_{\mathrm{m}}\right)$ as affected by the initial water source and freezing duration (mean \pm standard deviation, $n=3$; conditions: freezing temperature $249.15 \mathrm{~K}$, initial sample volume $50 \mathrm{~mL}$, simulated water contained $10 \mathrm{mg} / \mathrm{L}$ spiked fluoride)

chemicals on impurity migration have been well described in the literature (Baker 1967; Halde 1980; Melak et al. 2016). Looking into the variation in removal efficiency of fluoride in multi-ion existence, within the given conditions (see Fig. 3, with $10 \mathrm{mg} / \mathrm{L}$ initial fluoride concentration), percent removal was found in the order: aqueous solutions of $10 \mathrm{mg} / \mathrm{L} \mathrm{F}^{-}(2.72 \mu \mathrm{S} / \mathrm{cm})>$ tap water spiked with $10 \mathrm{mg} / \mathrm{L}$
$\mathrm{F}^{-}(97.2 \mu \mathrm{S} / \mathrm{cm})>$ simulated water spiked with $10 \mathrm{mg} / \mathrm{L}$ $\mathrm{F}^{-}(2630 \mu \mathrm{S} / \mathrm{cm})$. Several possible reasons for fluoride reduced removal efficiency in the presence of multiple ions include: similar charge and size of $\mathrm{F}^{-}$(ionic radius 1.33 $\AA$ ) with hydroxyl ion (ionic radius $1.32 \AA$ ) (Selinus et al. 2010), being anions are expected to be more solvated (calculated from hydration free energies) compared to cations of equal size (Hummer et al. 1996), fluoride being a kosmotropic ion which contributes to the stability and structure of water-water molecule possessing stronger interactions than chaotropic ions (Dos Santos et al. 2010). The class of kosmotrope and chaotrope ions is based on the effect on stability and structure of water-water interactions. Kosmotrope is the term explaining ion hydration which contributes to stability and structure of water-water interactions, leading to the favorable interaction of ions with water molecules. On the other hand, the chaotrope stands expressing weakly held hydration shells with low charge density and with weaker interactions with water molecules. These parameters collectively induced more inclusion of fluoride into ice phases (Parsons and Ninham 2011; Kang et al. 2014). The effect of multi-ion existence and their respective removal order efficiencies using freeze desalination has been investigated in our previous work (Melak et al. 2016).

To study whether the mass of ice produced is greater when simulated water is spiked with $10 \mathrm{mg} / \mathrm{L} \mathrm{F}^{-}$compared to double-distilled water spiked with $10 \mathrm{mg} / \mathrm{L} \mathrm{F}^{-}$, each water source sample was frozen over the freezing time span and the mass fraction of ice produced is illustrated in Fig. 4.

The energy estimated per liter of water is presented for each initial solution/simulated water source in Table 2 . The energy consumption for each case was found to be 91.8 , 93.9, and $111.9 \mathrm{~kJ} / \mathrm{L}$ for pure water, tap water spiked with $10 \mathrm{mg} / \mathrm{L} \mathrm{F}^{-}$, and simulated water spiked with $10 \mathrm{mg} / \mathrm{L} \mathrm{F}^{-}$, respectively. A higher energy consumption was observed for simulated water spiked with $10 \mathrm{mg} / \mathrm{L} \mathrm{F}^{-}$and tap water spiked with $10 \mathrm{mg} / \mathrm{L} \mathrm{F}^{-}$, over pure water. These energy differences, i.e., the increase in energy consumption in association with increase in salt ions, would be due to the energy

Table 2 Energy consumption and freezing point depression for sample water/solution

\begin{tabular}{lll}
\hline Item & $\begin{array}{l}\text { Energy } \\
\text { consumption } \\
(\mathrm{KJ} / \mathrm{L})\end{array}$ & $\begin{array}{l}\text { Freezing point } \\
\text { depression } \\
\left({ }^{\circ} \mathrm{C}\right)\end{array}$ \\
\hline Pure water (double-distilled water) & 91.8 & 0.0 \\
$\begin{array}{l}\text { Tap water spiked with } 10 \mathrm{mg} / \mathrm{L} \mathrm{F}^{-} \\
\begin{array}{l}\text { Simulated water spiked with } \\
10 \mathrm{mg} / \mathrm{L} \mathrm{F}^{-}\end{array}\end{array}$ & 93.9 & $\mathrm{NR}$ \\
\hline
\end{tabular}

Freezing temperature set at $249.15 \mathrm{~K}$, freezing duration of $2 \mathrm{~h}$, and initial volume of $50 \mathrm{~mL}$

NR: not reported/calculated 
upon freezing point depression temperature changes. Recent literature showed that freeze desalination plants are currently much more effective than they were in the past due to renewable energy applications. The possibility of replacing conventional refrigerant compressors by renewable resources (e.g., use of hydraulic refrigerant compressors) was found energy efficient (Rice and Chau 1997; Chang et al. 2016; Melak et al. 2016).

\section{Energy and cost overview}

The energy consumption and cost of desalination technologies depend on the type of process (thermal or membrane process) involved and also with other parameters such as feed water quality, pre-treatment, plant capacity, plant life, investment assets, energy and labor costs, and environmental restrictions. The cost of desalination is also dependent on transport costs and the type of the project contract. In addition to capital and operating costs, incentives or subsidies also contribute to the large difference in desalted water cost between regions and facilities. For instance, cost of desalination of seawater has reduced to below $\$ 0.50 / \mathrm{m}^{3}$ for a large-scale seawater reverse osmosis plant at a specific location while in other locations the cost has been shown to double $\left(\$ 1.00 / \mathrm{m}^{3}\right)$ in similar conditions (Ghaffour et al. 2013). With such accord, Table 3 shows an overview on the total average cost and energy consumption overview to foresee different method applications and to observe the weak sides. Energy consumption using freeze desalination is also affected by different factors, for instance, by the appliance used and where it is located, temperature, refrigeration cycle efficiency, and others. Direct comparison of our experimental results with literature data would create ambiguity because the data for the literature in Table 3 are for largescale commercial aspects. At this point in time, it could be forwarded that hybrid methods with freezing and reverse osmosis (RO) showing 25\% energy saving and the possibility of using renewable energy sources like LNG would make freeze desalination as future aspired technology (Baayyad et al. 2014; Chang et al. 2016).

\section{Fraction of ice volume}

Theoretically, the ice floats on water due to the density of water in liquid phase being greater than in the ice phase. In this experiment, the liquid water residue during the partial freezing process is imbedded within the ice crystals. This is mainly because the ice nucleation started at the interface of the container and the water phases. Such phenomenon was also noticed as seawater was frozen, impurities had concentrated into the center of the ice block (Nebbia and Menozzi 1968). The tendency of concentrated water being present in the center of the ice block and freeze separation efficiency decrement are highly dependent on the volume of the container. Thus, freeze separation efficiency of contaminants decreases when residual liquid volume is getting very small (Baker 1967; Halde 1980). The fraction of ice mass produced as per total solution is well described in Fig. 4 for small volume containers, a capped plastic beakers of $(4 \mathrm{~cm}$ height by $2.5 \mathrm{~cm}$ radius); however, in using rectangular base of about $8 \mathrm{~cm}$ by $6 \mathrm{~cm}$ plastic beaker the ice tends to float (data not shown for higher volume of sample solutions).

\section{Application of tap water sources}

The physicochemical parameters of tap water used in the experiment are described in Table 4 . The results of freeze desalination upon the tap water spiked with $10 \mathrm{mg} / \mathrm{L} \mathrm{F}^{-}$are illustrated in "Effect of fluoride concentration and multiion occurrence" section. The technical challenges such as

Table 3 Energy consumption and total water cost of large-scale commercial desalination processes

\begin{tabular}{|c|c|c|c|c|}
\hline Methods & $\begin{array}{l}\text { Total } \\
\text { energy } \\
\mathrm{kWh} / \mathrm{m}^{3}\end{array}$ & Total average costs & Remark & References \\
\hline Thermal: multistage flash (MSF) evaporation & $10-16$ & $1.0 \$ / \mathrm{m}^{3}$ & $\begin{array}{l}\text { Second largest installed desalting } \\
\text { capacity in the world next to RO }\end{array}$ & Zhou and Tol (2005) \\
\hline Thermal: multiple effect (ME) evaporation & $5.5-9$ & about $\$ 1.0 / \mathrm{m}^{3}$ & & Ghaffour et al. (2013) \\
\hline Thermal: vapor compression (VC) & $\begin{array}{l}3-4 \\
0.5-2.5\end{array}$ & $\begin{array}{l}\$ 1.0 / \mathrm{m}^{3} \\
\$ 1.0 / \mathrm{m}^{3}\end{array}$ & $\begin{array}{l}\text { For seawater desalination } \\
\text { for brackish water desalination }\end{array}$ & Ettouney and Wilf (2009) \\
\hline Membrane processes: reverse osmosis(RO) & 5 & less than $\$ 0.5 / \mathrm{m}^{3}$ & for seawater & $\begin{array}{l}\text { Ettouney and Wilf (2009 } \\
\text { and Ghaffour et al. } \\
\text { (2013) }\end{array}$ \\
\hline Electrodialysis (ED) & & $\begin{array}{l}\text { less than } \$ 1.0 / \mathrm{m}^{3} \\
\text { about } \$ 0.6 / \mathrm{m}^{3}\end{array}$ & $\begin{array}{l}\text { For seawater } \\
\text { Brackish water desalination }\end{array}$ & Zhou and Tol (2005) \\
\hline $\begin{array}{l}\text { Hybrid method: coupling freezing and reverse } \\
\text { osmosis (RO) }\end{array}$ & 1.25 & & for seawater & Baayyad et al. (2014) \\
\hline
\end{tabular}


Table 4 Physicochemical parameters of the tap water used in the experiment

\begin{tabular}{ll}
\hline Parameters & Concentration \\
\hline $\mathrm{pH}$ & 6.72 \\
Turbidity, NTU & 8.11 \\
TDS, mg/L & 200 \\
Chloride, mg/L & 4.50 \\
Nitrate, mg/L & 0.79 \\
Total hardness, mg/L & 34 \\
Iron, mg/L & 0.20 \\
Magnesium, mg/L & 16.1 \\
Calcium, mg/L & 18 \\
Conductivity, $\mu$ S/cm & 95.7 \\
Alkalinity (by bicarbonate), mg/L & 18.0 \\
\hline
\end{tabular}

increasing the water rejection due to melting the ice while washing, and variability on removal efficiency depending on the washing steps are to be noted to advance the technique. The simultaneous reduction of important ions such as $\mathrm{Na}^{+}$, $\mathrm{K}^{+}$, and other ions found in water from the water sources during freeze desalination also inquire special attention when designing the technology for practical applications.

\section{Conclusion}

Freeze defluoridation efficiency depends on various factors, which include freezing temperature, initial concentration, and volume of container, freeze duration, salinity, and turbidity. Freeze defluoridation was found effective at wide range of concentrations $(2-20 \mathrm{mg} / \mathrm{L})$, showing $55-62 \%$ freeze separation of fluoride from aqueous solutions. Freeze separation efficiency of fluoride was found to be $48 \%$ for tap water spiked with $10 \mathrm{mg} / \mathrm{L} \mathrm{F}^{-}$, with small volume rejection $(10-15 \%)$ of initial volume.

Acknowledgements The authors are thankful to Jimma University, Ethiopia, for the financial and material support.

Open Access This article is distributed under the terms of the Creative Commons Attribution 4.0 International License (http://creativeco mmons.org/licenses/by/4.0/), which permits unrestricted use, distribution, and reproduction in any medium, provided you give appropriate credit to the original author(s) and the source, provide a link to the Creative Commons license, and indicate if changes were made.

\section{References}

Adeniyi A, Mbaya RKK, Onyango MS, Popoola API, Maree JP (2016) Efficient suspension freeze desalination of mine wastewaters to separate clean water and salts. Environ Chem Lett 14(4):449-454. https://doi.org/10.1007/s10311-016-0562-6

Amini M, Mueller K, Abbaspour KC, Rosenberg T, Afyuni M, Møller KN, Sarr M, Johnson CA (2008) Statistical modeling of global geogenic fluoride contamination in groundwaters. Environ Sci Technol 42:3662-3668. https://doi.org/10.1021/es071958y

Ayoob S, Gupta AK (2006) Fluoride in drinking water: a review on the status and stress effects. Crit Rev Environ Sci Technol 36:433487. https://doi.org/10.1080/10643380600678112

Baayyad I, Hassani NSA, Bounahmidi T (2014) Evaluation of the energy consumption of industrial hybrid seawater desalination process combining freezing system and reverse osmosis. Desalin Water Treat 56(10):37-41. https://doi.org/10.1080/19443 994.2014.968901

Badawy SM (2015) Laboratory freezing desalination of seawater. Desalin Water Treat 57:11040-11047. https://doi. org/10.1080/19443994.2015.1041163

Baker RA (1967) Trace organic contaminant concentration by freezing-I. Low inorganic aqueous solutions. Water Res 1:65-77. https://doi.org/10.1016/0043-1354(67)90064-4

Cao W, Beggs C, Mujtaba IM (2015) Theoretical approach of freeze seawater desalination on flake ice maker utilizing LNG cold energy. Desalination 355:22-32. https://doi.org/10.1016/j.desal .2014 .09 .034

Chang J, Zuo J, Lu K, Chung T (2016) Freeze desalination of seawater using LNG cold energy. Water Res 1:1. https://doi. org/10.1016/j.watres.2016.06.046

Dos Santos AP, Diehl A, Levin Y (2010) Surface tensions, surface potentials, and the Hofmeister series of electrolyte solutions. Langmuir 26:10778-10783. https://doi.org/10.1021/la100604k

Durmaz F, Kara H, Cengeloglu Y, Ersoz M (2005) Fluoride removal by donnan dialysis with anion exchange membranes. Desalination 177:51-57. https://doi.org/10.1016/j.desal.2004.11.016

Eaton AD, Clesceri LS, Greenberg AE (eds) (1995) Standard methods for the examination of water and wastewater. American Public Health Association, Washington, DC

ESA (2013) Ethiopian drinking water quality standard. First edition. Compulsory Ethiopian Standard (CES 58)

Ettouney H, Wilf M (2009) Conventional thermal process. In: Micale G, Rizzuti L, Cipollina A (eds) Seawater desalination: conventional and renewable energy processes. Springer, Berlin, p 306

Fawell JK, Bailey K, Chilton J, Dahi E, Fewtrell L, Magara Y (2006) Fluoride in drinking-water. IWA, London

Fletcher N (1966) The freezing of water. Sci Prog 54:227-241

Ghaffour N, Missimer TM, Amy GL (2013) Technical review and evaluation of the economics of water desalination: current and future challenges for better water supply sustainability. Desalination 309:197-207. https://doi.org/10.1016/j.desal .2012.10.015

Laporte-Saumure M, Martel R, Mercier G (2010) Evaluation of physicochemical methods for treatment of $\mathrm{Cu}, \mathrm{Pb}, \mathrm{Sb}$, and $\mathrm{Zn}$ in canadian small arm firing ranges backstop soils. Water Air Soil Pollut 213:171. https://doi.org/10.1007/s11270-010-0376-2

Halde R (1980) Concentration of impurities by progressive freezing. Water Res 14:575-580. https://doi.org/10.1016/00431354(80)90115-3

Hao P, Lv C, Zhang X (2014) Freezing of sessile water droplets on surfaces with various roughness and wettability. Appl Phys Lett 10(1063/1):4873345

Hosseini SS, Mahvi AH, Hosseini SA (2012) Freezing process a new approach for fluoride removal. In: XXXth conference of the international society for fluoride research. Szczecin, Poland, pp $151-218$

Hummer G, Pratt LR, García AE (1996) Free energy of ionic hydration. J Phys Chem 100:1206-1215. https://doi.org/10.1021/ jp951011v

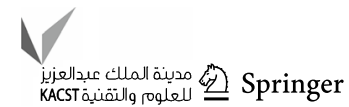


Jagtap S, Yenkie MK, Labhsetwar N, Rayalu S (2012) Fluoride in drinking water and defluoridation of water. Chem Rev 112(4):2454-2466. https://doi.org/10.1021/cr2002855

Kang KC, Linga P, Park K et al (2014) Seawater desalination by gas hydrate process and removal characteristics of dissolved ions $\left(\mathrm{Na}^{+}, \mathrm{K}^{+}, \mathrm{Mg}^{2+}, \mathrm{Ca}^{2+}, \mathrm{B}^{3+}, \mathrm{Cl}^{-}, \mathrm{SO}_{4}{ }^{2-}\right)$. Desalination 353:8490. https://doi.org/10.1016/j.desal.2014.09.007

Knopf DA, Alpert PA (2013) A water activity based model of heterogeneous ice nucleation kinetics for freezing of water and aqueous solution droplets. Faraday Discuss 165:513. https:// doi.org/10.1039/c3fd00035d

Liu L, Miyawaki O, Nakamura K (1997) Progressive freeze-concentration of model liquid food. Food Sci Technol Int Tokyo $3: 348-352$

Lorain O, Thiebaud P, Badorc E, Aurelle Y (2001) Potential of freezing in wastewater treatment: soluble pollutant applications. Water Res 35:541-547. https://doi.org/10.1016/S0043-1354(00)00287-6

$\mathrm{Lu} \mathrm{Z}, \mathrm{Xu} \mathrm{L}$ (2010) Freezing desalination process. Thermal desalination process Vol. II. Encyclopedia of Desalination and Water Resources (DESWARE). A UNSCO-EOLSS sample chapter.

Mahdavi M, Mahvi AH, Nasseri S, Yunesian M (2011) Application of freezing to the desalination of saline water. Arab J Sci Eng 36:1171-1177. https://doi.org/10.1007/s13369-011-0115-z

Melak F, Du Laing G, Ambelu A, Alemayehu E (2016) Application of freeze desalination for chromium (VI) removal from water. Desalination 377:23-27. https://doi.org/10.1016/j.desal.2015.09.003

Mettler-Toledo AG (2011) perfectION ${ }^{\mathrm{TM}}$ combination fluoride electrode successful ion measurement. An instrumental manual. Switzerland

Mohapatra M, Anand S, Mishra BK, Giles DE, Singh P (2009) Review of fluoride removal from drinking water. J Environ Manag 91:6777. https://doi.org/10.1016/j.jenvman.2009.08.015

Mtombeni T, Maree JP, Zvinowanda CM et al (2013) Evaluation of the performance of a new freeze desalination technology. Int $\mathrm{J}$ Environ Sci Technol 10:545-550. https://doi.org/10.1007/s1376 2-013-0182-7

Nebbia G, Menozzi GN (1968) Early experiments on water desalination by freezing. Desalination 5:49-54. https://doi.org/10.1016/S0011 -9164(00)80191-5

Niedermeier D, Shaw RA, Hartmann S, Wex H, Clauss T, Voigtander J, Stratmann F (2011) Heterogeneous ice nucleation: exploring the transition from stochastic to singular freezing behavior. Atmos Chem Phys 11:8767-8775. https://doi.org/10.5194/ acp-11-8767-2011

Parsons DF, Ninham BW (2011) Surface charge reversal and hydration forces explained by ionic dispersion forces and surface hydration. Colloids Surf A Physicochem Eng Asp 383:2-9. https://doi. org/10.1016/j.colsurfa.2010.12.025

Rahman MS, Ahmed M, Chen XD (2006) Freezing-melting process and desalination: I. Review of the state-of-the-art. Sep Purif Rev 35:59-96. https://doi.org/10.1080/15422110600671734

Rango T, Kravchenko J, Atlaw B et al (2012) Groundwater quality and its health impact: an assessment of dental fluorosis in rural inhabitants of the Main Ethiopian Rift. Environ Int 43:37-47. https://doi.org/10.1016/j.envint.2012.03.002

Reimann C, Bjorvatn K, Frengstad B et al (2003) Drinking water quality in the Ethiopian section of the East African Rift Valley Idata and health aspects. Sci Total Environ 311:65-80. https://doi. org/10.1016/S0048-9697(03)00137-2

Rice W, Chau DSC (1997) Freeze desalination using hydraulic refrigerant compressors. Desalination 109:157-164. https://doi. org/10.1016/S0011-9164(97)00061-1

Selinus O, Finkelman RB, Centeno JA (2010) Medical geology: a regional synthesis. Springer, Dordrecht

Shone RDC (1987) The freeze desalination of mine waters. J S Afr Inst Min Met 87:107-112

Tahir MA, Rasheed H (2013) Fluoride in the drinking water of Pakistan and the possible risk of crippling fluorosis. Drink Water Eng Sci 6:17-23. https://doi.org/10.5194/dwes-6-17-2013

Tansel B (2012) Significance of thermodynamic and physical characteristics on permeation of ions during membrane separation: hydrated radius, hydration free energy and viscous effects. Sep Purif Technol 86:119-126. https://doi.org/10.1016/j.seppu r.2011.10.033

Tewodros T, Bianchini G, Beccaluva L, Tassinari R (2010) Geochemistry and water quality assessment of central main Ethiopian Rift natural waters with emphasis on source and occurrence of fluoride and arsenic. J Afr Earth Sci 57:479-491. https://doi.org/10.1016/j. jafrearsci.2009.12.005

Thole B (2013) Ground water contamination with fluoride and potential fluoride removal technologies for East and Southern Africa. In: Dar IA, Dar MA (eds) Perspectives in water pollution. Intech, London, p 224

Vrbka L, Jungwirth P (2005) Brine rejection from freezing salt solutions: a molecular dynamics study. Phys Rev Lett 95:148501148504. https://doi.org/10.1103/PhysRevLett.95.148501

Wang P, Chung T (2012) A conceptual demonstration of freeze desalination-membrane distillation (FD-MD) hybrid desalination process utilizing liquefied natural gas (LNG) cold energy. Water Res 46:4037-4052. https://doi.org/10.1016/j.watres.2012.04.042

Wright TP, Petters MD (2013) The role of time in heterogeneous freezing nucleation. J Geophys Res Atmos 118:3731-3743. https://doi. org/10.1002/jgrd.503652013

Zhou Y, Tol RSJ (2005) Evaluating the costs of desalination and water transport. Water Resour Res 41:1-10. https://doi. org/10.1029/2004WR003749

Zhou J, Lu X, Wang Y, Shi J (2002) Molecular dynamics study on ionic hydration. Fluid Phase Equilib 194-197:257-270. https:// doi.org/10.1016/S0378-3812(01)00694-X

Publisher's Note Springer Nature remains neutral with regard to jurisdictional claims in published maps and institutional affiliations. 